\title{
RESPON PERTUMBUHAN RUMPUT SETARIA (Setaria sphacelata) YANG DIBERI PUPUK KOTORAN SATWA KUSKUS PADA DEFOLIASI KEDUA
}

\author{
Sriani Nauw, Diana Sawen*, Lamberthus Nuhuyanan, dan Muhammad Junaidi \\ 1,2,3,4 Fakultas Peternakan Univesitas Papua, \\ *Korespondensi e-mail: sawendian@yahoo.com; d.sawen@unipa.ac.id
}

\begin{abstract}
ABSTRAK
Penelitian ini bertujuan untuk mengetahui respon pertumbuhan rumput setaria (Setaria sphacelata) yang diberikan pupuk kotoran satwa kuskus asal penangkaran pada defoliasi kedua. Penelitian dilakukan selama 3 bulan berlokasi di Jl. Flamboyan B.18 Amban Manokwari Papua Barat. Penelitian didesain dengan rancangan acak lengkap (RAL) dengan 3 perlakuan dan 5 ulangan. Perlakuan yang diberikan antara lain: $\mathrm{Po}=$ kontrol (tanpa pupuk); $\mathrm{P} 1=$ Pupuk kotoran satwa kuskus berbasis pakan pisang; dan $\mathrm{P} 2=$ pupuk kotoran satwa kuskus berbasis pakan avokad. Hasil penelitian menunjukkan bahwa pemberian pupuk kotoran satwa kuskus berbasis pakan pisang dan avokad memberikan pengaruh signifikan terhadap pertumbuhan tinggi tanaman, jumlah daun, dan jumlah anakan rumput Setaria sphacelata. Rataan tinggi tanaman, jumlah daun, dan jumlah anakan terbaik dihasilkan pada perlakuan P1 berturut-turut adalah 52,98 $\pm 2,34$ $\mathrm{cm}, 74,63 \pm 18,46$ helai daun, dan $16,30 \pm 4,97$ anakan. Perlakuan pemberian pupuk kotoran satwa kuskus memberikan hasil optimal pada pertumbuhan rumput setaria.
\end{abstract}

Kata kunci: Setaria sphacelata, pupuk organik, pertumbuhan

\section{GROWTH RESPONSE OF SETARIA GRASS (Setaria sphacelata) ON APPLICATION OF CUSCUS MANURE IN THE SECOND DEFOLIATION}

\begin{abstract}
This study aims to determine the response to the growth of setaria grass (Setaria sphacelata) on application cuscus manure from captivity in the second defoliation. The research was conducted for 3 months, located on Jl. Flamboyant B.18 Amban Manokwari, West Papua. The study was designed with a completely randomized design (CRD) with 3 treatments and 5 replications. The treatments given included: Po $=$ control (without fertilizer); $\mathrm{P} 1=$ cuscus animal manure based on banana feed; and P2 = cuscus animal manure based on avocado feed. The results showed that the application of cuscus' manure fertilizer based on banana and avocado feed had a significant effect on the growth of plant height, number of leaves and number of Setaria spachelata tillers. The best average plant height, number of leaves and number of tillers produced in the P1 treatment were $52.98 \pm 2.34 \mathrm{~cm}, 74.63 \pm 18.46$ leaves, and $16.30 \pm 4.97$ tillers, respectively. The treatment of cuscus manure gave optimal results on the growth of Setaria grass.
\end{abstract}

\section{Keyword: Setaria sphacelata, organic fertilizer, growth}

\section{PENDAHULUAN}

Keberhasilan suatu usaha peternakan ruminansia sangat tergantung kepada kemampuan peternak untuk menyediakan hijauan pakan ternak yang berkualitas tinggi dalam jumlah yang cukup dan secara kontinyu tersedia sepanjang tahun. Guna mendapatkan hijauan makanan ternak yang tinggi produksinya, diperlukan suatu penguasaan teknik dalam membudidayakan hijauan makanan ternak tersebut mulai dari tahap pengolahan tanah, pemilihan bibit, penanaman, pemupukan, penyiangan dan pemanenan.

Rumput setaria merupakan salah satu spesies tanaman yang mempunyai kualitas yang baik sebagai hijauan pakan ternak, jika dilihat dari tingkat pertumbuhan, produktivitas atau hasil panen maupun nilai nutrisinya. Pemupukan juga dibutuhkan oleh tanaman untuk keperluan pertumbuhan dan produksi (Wulandari et al. 2021). Selain pemupukan, tanah sendiri telah menyediakan unsur hara dan mineral yang cocok untuk tanaman. Namun, dalam jangka waktu panjang persediaan unsur hara dan mineral dalam tanah semakin berkurang, karena diserap oleh tanaman. Menurut Lingga (2002) bahwa pemupukan merupakan kunci dari kesuburan tanah karena satu atau lebih unsur hara untuk menggantikan unsur hara yang habis diserap oleh tanaman. karena itu dalam pemupukan ada tiga hal yang penting dan tidak 
dapat dipisahkan yaitu tanah, tanaman dan pupuk.

Pupuk kandang adalah pupuk organik yang berasal dari kotoran ternak, baik berupa kotoran padat (feses) yang bercampur sisa pakan, ataupun air kencing (urin). Pakan mempunyai pengaruh yang sangat penting dalam menentukan kadar hara, jika pakan diberikan banyak mengandung hara N, P, dan $\mathrm{K}$ maka kotorannya pun akan kaya dengan zat tersebut (Hartono, 2011). Kotoran satwa yang biasanya dimanfaatkan sebagai pupuk organik adalah guano dari kelelawar yang mengandung banyak unsur $\mathrm{K}$ (kalium). Jenis pakan yang dikonsumsi satwa kuskus yaitu buah-buahan, pucuk dan dedaunan pohon di hutan (Sawen dan Sineri, 2020) dan sudah banyak didokumentasikan dalam riset-riset untuk tujuan konservasi dan edukasi.

Hasil penelitian Marliani (2010) menunjukkan penanaman rumput setaria dengan jenis pupuk kandang feses ayam dan feses sapi dengan dosis 150 gram/polybag dapat meningkatkan produksi rumput setaria. Niknik et al. (2014), juga melaporkan hal yang sama, bahwa penambahan pupuk kotoran feses ayam petelur dan larutan EM4, mampu meningkatkan pertumbuhan (tinggi tanaman, jumlah daun, jumlah anakan) dan produktivitas rumput setaria pada defoliasi pertama dan kedua. Penanaman jenis hijauan pakan dengan pupuk organik seperti feses kuskus belum banyak dilakukan, dengan demikian penelitian ini dilakukan untuk mengetahui sejauh mana pertumbuhan rumput setaria berbasis pupuk organik feses kuskus pada defoliasi kedua.

\section{MATERI DAN METODE}

\section{Tempat dan Waktu Penelitian}

Penelitian dilaksanakan di Jl Flamboyan B.18 Amban Manokwari dengan lama waktu penelitian 3 bulan yaitu bulan Maret sampai dengan Mei 2020.

\section{Bahan dan Alat}

Bahan yang digunakan dalam penelitian antara lain: pols rumput setaria (Setaria sphacelata) berukuran $\pm 20 \mathrm{~cm}$, tanah, polybag ukuran $30 \times 25 \mathrm{~cm}^{2}$ berwarna hitam dengan kapasitas $5 \mathrm{~kg}$, pupuk feses kuskus dengan dosis pemberian 40 gram/polybag. Sedangkan alat yang digunakan terdiri dari cangkul, parang, cutter, pita ukur/penggaris ukuran $100 \mathrm{~cm}$, ember, ayakan tanah dari kawat dengan ukuran 0,5 mm (35 mesh), timbangan digital camry kapasitas $5 \mathrm{~kg}$ dan $2 \mathrm{~kg}$ dengan tingkat ketelitian o,01 gram, karung plastik, tali rafia, kamera, gunting stek, thermohigrometer, dan alat tulis.

\section{Rancangan Percobaan}

Penelitian ini didesain dalam rancangan acak lengkap (RAL) dengan 3 perlakuan dan 5 ulangan. Perlakuan yang diberikan yaitu: $\mathrm{Po}=$ kontrol $(100 \%$ tanah); $\mathrm{P} 1=$ pupuk feses kuskus berbasis pakan pisang, dosis 40 gram/polybag; P2= pupuk feses kuskus berbasis pakan avokad, 40 gram/polybag.

\section{Pelaksanan Penelitian}

Persiapan Media Tanam. Tanah yang digunakan berasal dari Taman Ternak Fakultas Peternakan UNIPA Manokwari. Tanah yang sudah diambil, dijemur selama 1 minggu untuk mematikan jamur dan bakteri yang terkandung di dalamnya setelah itu tanah dibersihkan dari ranting kayu dan batu menggunakan ayakan kawat berukuran 0,5 mm (35 mesh) sehingga tanah menjadi halus dan steril. Selanjutnya tanah dimasukkan dalam polybag, dengan berat 5 kg. Perlakuan P1 dan P2, tanah pada masing-masing polybag dicampurkan dengan pupuk kotoran satwa kuskus sesuai dosisnya yaitu 1:1 (v/v) (Hadisuwito, 2012). Dosis pemberiannya didasarkan pada kebutuhan pupuk organik untuk rumput yaitu 20 ton/ha.

Persiapan Bibit. Bibit rumput setaria yang ditanam yaitu pols yang berasal dari tanaman yang sudah dewasa, yang dipotong dengan ukuran 15-20 cm dengan jumlah sesuai satuan percobaan. Pols dibersihkan dari pelepah kering dan petiole yang melekat pada bagian pols, ini bertujuan agar mempercepat pertumbuhan akar pada saat rumput ditanam.

Penanaman. Setelah tanah di dalam polybag, bibit setaria dan pupuk feses kuskus sudah siap, feses yang akan digunakan dipisahkan sesuai perlakuan masing-masing. Selanjutnya masing-masing tanah pada polybag dikeluarkan pada wadah karung plastik untuk memudahkan pencampuran secara merata dengan pupuk kotoran kuskus dan dimasukkan kembali ke dalam polybagnya. Pemupukan ini hanya diberikan sekali. Penanaman dilakukan pada sore hari, dengan menanam 1 pols dalam setiap polybag. Penanaman dilakukan secara hati-hati agar tidak merusak bagian pols tersebut, dengan kedalaman $5 \mathrm{~cm}$. Selanjutnya polybag diatur sesuai dengan denah penempatan perlakuan. Jarak antar polybag adalah $50 \mathrm{~cm}$.

Penyeragaman (Trimming) I dan Defoliasi I. Tujuan trimming atau penyeragaman adalah untuk merangsang pertumbuhan kembali dan menyeragamkan pertumbuhan pada periode berikutnya (Lakitan, 2007). Setelah pols rumput setaria yang ditanam bertumbuh, dilakukan trimming setelah 14 hari (dua minggu) dengan jarak pemotongan $15 \mathrm{~cm}$ di atas permukaan tanah. Selanjutnya tanaman setaria dipelihara hingga umur 40 hari, baru kemudian dilakukan defoliasi pertama. Sedangkan selanjutnya tanaman rumput setaria dipelihara kembali untuk pengamatan dalam penelitian ini.

Pemeliharaan. Pemeliharaan rumput setaria 
dilakukan dengan penyiraman yang rutin dua kali sehari, yaitu pada pagi hari pukul 08.00 WIT dan sore hari pukul 17.0o WIT sampai tanaman tumbuh dengan baik. Frekuensi penyiraman disesuaikan dengan kondisi cuaca, apabila cuacanya panas maka dilakukan penyiraman dan sebaliknya apabila hujan maka tidak dilakukan penyiraman. Selanjutnya dilakukan penyiangan terhadap gulma atau tumbuhan liar yang tumbuh di sekitar rumput setaria di dalam polybag, dilakukan setiap minggu sekali. Sedangkan penyulaman tidak dilakukan karena selama penelitian, tidak ada tanaman setaria yang mati.

Pengamatan. Pengamatan dilakukan setiap minggu berjalan selama penelitian untuk mengukur tinggi tanaman, jumlah daun, dan jumlah anakan. Tinggi tanaman diukur dengan menggunakan penggaris dan pita ukur, sedangkan jumlah anakan dan jumlah daun, dihitung per polybag dengan memberi tanda ikatan tali rafia pada daun dan anakan yang sudah dihitung, agar mempermudah perhitungan selanjutnya.

Analisis Data. Data pengamatan yang diperoleh dihitung dan dianalisis secara statistik dengan analisis sidik ragam (Anova) sesuai rancangan acak lengkap menggunakan software statistik SPSS versi 22. Perlakuan yang memberikan pengaruh nyata $(\mathrm{P}<0,05)$ dilanjutkan dengan uji lanjut Beda Nyata Jujur (BNJ) (Steel dan Torrie, 1993).

\section{HASIL DAN PEMBAHASAN}

Hasil yang diperoleh selama pengamatan yang di lapangan, meliputi: rataan tinggi tanaman, jumlah daun, dan jumlah anakan rumput Setaria (Setaria spacelata) disajikan pada Tabel 1.

Tabel 1. Hasil Analisis Ragam (Anova) pada Setiap Variabel Pengamatan

\begin{tabular}{lccc}
\hline \multirow{2}{*}{ Variabel Pengamatan } & \multicolumn{3}{c}{ Perlakuan } \\
\cline { 2 - 4 } & Po & P1 & P2 \\
\hline Tinggi tanaman (cm) & $45,61 \pm 3,98^{\mathrm{a}}$ & $52,98 \pm 2,34^{\mathrm{b}}$ & $54,30 \pm 2,35^{\mathrm{b}}$ \\
Jumlah anakan & $11,12 \pm 2,17^{\mathrm{a}}$ & $16,30 \pm 4,97^{\mathrm{b}}$ & $15,28 \pm 1,35^{\mathrm{ab}}$ \\
(anakan) & & & \\
Jumlah daun (helai) & $59,91 \pm 13,95$ & $74,63 \pm 18,46$ & $65,51 \pm 7,92$ \\
\hline
\end{tabular}

Keterangan: huruf dengan superskrip berbeda pada lajur yang sama dengan kolom berbeda menunjukkan perbedaan nyata $(\mathrm{P}<0,05)$.

\section{Tinggi Tanaman}

Tinggi tanaman setaria semakin meningkat dengan adanya perlakuan penambahan pupuk kotoran kuskus. Hasil analisis ragam (Tabel 1) menunjukkan bahwa perlakuan kontrol (Po) dan pemberian pupuk kotoran kuskus berbasis pisang $(\mathrm{P} 1)$ dan berbasis avokad ( $\mathrm{P} 2)$ berpengaruh nyata $(\mathrm{P}<0,05)$ terhadap tinggi tanaman. Perlakuan P1 dan P2 nyata memberikan pengaruh pertambahan tinggi rumput setaria sebesar 1,32 cm. Hal ini karena pupuk kotoran satwa kuskus berbasis buah pisang dan avolad yang diberikan memiliki kandungan unsur hara berupa $\mathrm{N}, \mathrm{P}$, dan K yang dibutuhkan oleh setaria untuk bertumbuh. Hasil analisis kandungan mineral kotoran kuskus dapat dilihat pada Tabel 2.

Tabel 2. Hasil Analisis Kandungan Mineral Kotoran Satwa Kuskus

\begin{tabular}{lccc}
\hline Feses satwa kuskus & $\mathrm{N}(\%)$ & $\mathrm{P}(\%)$ & $\mathrm{K}(\%)$ \\
\hline Berbasis pisang & 0,85 & 0,61 & 3,20 \\
Berbasis avokad & 0,76 & 0,12 & 2,56 \\
\hline
\end{tabular}

Sumber: Mauri et al. (2021)

Laju pertumbuhan tinggi tanaman per minggu meningkat seiring dengan waktu atau umur tanaman setaria saat defoliasi pertama. Peningkatan ini terjadi karena dosis pupuk kotoran satwa kuskus yang diberikan pada perlakuan mampu diserap oleh rumput setaria sehingga secara simultan menghasilkan pertumbuhan yang baik. Hal ini ditunjang dengan hasil penelitian Rini (2011) bahwa pemberian pupuk organik pada tanaman dapat merangsang pertumbuhan akar, batang, dan daunnya. Salah satu unsur hara yang berperan penting dalam pertumbuhan tanaman adalah nitrogen $(\mathrm{N})$.

Hasil uji lanjut beda nyata jujur (BNJ) menunjukkan bahwa perlakuan Po berbeda nyata dengan perlakuan P1dan P2 terhadap pertumbuhan tinggi tanaman, namun pada perlakuan P1dan P2 tidak berbeda nyata. Hal ini terjadi karena jumlah unsur hara yang diterima oleh kedua perlakuan (P1 dan $\mathrm{P} 2)$ lebih banyak dan dosisnya sama daripada perlakuan kontrol sehingga menyediakan unsur hara yang baik untuk menunjang peningkatan pertumbuhan rumput setaria. $\mathrm{N}$ kotoran kuskus berbasis pisang $0,85 \%$ dan dari avokad sebesar 0,76\% (Tabel 2), mampu berakumulasi dengan tanah pada media tanam sehingga menunjang proses fotosntesis pada rumput setaria (Muhakka et al., 2013). Hal ini sesuai Salisburry dan Ross (1995) bahwa pertambahan tinggi tanaman merupakan proses fisiologi dengan adanya indikator pembelahan sel. Proses pembelahan sel tersebut, tanaman memerlukan unsur hara esensial dalam jumlah yang cukup agar dapat diserap melalui akar tanaman. Selain itu, ada dugaan bahwa penambahan pupuk kotoran kuskus dapat memperbaiki sifat sifik dan biologi tanah sehingga aktivitas mikroorganisme tanah meningkat dan mempengaruhi sifat kimia tanah menjadi lebih baik (Suningsih, 2019). Sedangkan pada perlakuan kontrol (Po) tidak mendapatkan tambahan pupuk feses kuskus sehingga tanaman rumput setaria tidak mendapatkan unsur hara yang cukup untuk memperbaiki struktur tanah yang berdampak pada pertumbuhan tanaman. Hal sejalan dengan pendapat Hartono (2012), bahwa pertumbuhan tanaman dan 
produksi akan tinggi apabila di dalam tanah terdapat unsur hara dengan jumlah yang seimbang dan laju pertumbuhan tanaman akan menurun apabila unsur hara yang diperlukan tidak tersedia. Penggunaan pupuk kotoran ternak dapat menyebabkan daya ikat air oleh tanah semakin menjadi lebih baik sehingga efektif membantu proses penyerapan unsur hara dan fotosintesis (Muhakka, 2012). Hal ini didukung oleh Fadludin et al. (2013) bahwa jika proses fotosintesis tidak berjalan dengan baik maka nutrisi tanaman juga akan sedikit sehingga dapat menurunkan atau menghambat pertumbuhan tanaman.

Hasil penelitian ini lebih tinggi bila dibandingkan dengan hasil penelitian yang dilaporkan oleh Niknik et al. (2014) bahwa rata-rata pertambahan tinggi tanaman rumput Setaria sphacelata dengan pemberian pupuk organik kotoran ayam petelur dengan dosis 98 gram/rumpun yang dipanen pada umur 90 hari yaitu 44,05 cm. Suningsih (2019), hasil tinggi tanaman setaria yang diperoleh adalah $85,58 \mathrm{~cm}$ untuk perlakuan dengan pupuk kotoran kambing dengan dosis 300 gram/polybag sehingga dapat menyatakan bahwa pupuk kotoran ternak menyediakan hara yang baik sehingga menunjang pertumbuhan tanaman.

\section{Jumlah Anakan}

Jumlah anakan merupakan salah satu bagian yang menunjukkan pertumbuhan dan perkembangan tanaman. Jumlah anakan juga ikut menentukan tinggi rendahnya bobot hijauan yang dihasilkan dan mempunyai peran tinjau dari fungsi sebagai hijauan pakan. Jumlah anakan yang dimaksud adalah semua individu yang masih muda yang muncul dari tanah dalam suatu rumpun, jadi berbeda dengan cabang yang muncul dari buku atau ruas.

Tabel 1 menunjukan bahwa rata- rata jumlah anakan yang dihasilkan rumput setaria pada tiap perlakuan, yang memberikan nilai lebih tinggi yaitu P1 16 anakan dan diikuti P2 sebanyak 15 anakan dan Po sebanyak 11 anakan. Hasil analisis statistik (Anova) menunjukkan bahwa perlakuan pupuk organik feses kuskus berpengaruh nyata $(\mathrm{P}<0,05)$ terhadap jumlah anakan rumput setaria. Hasil ini juga memperlihatkan bahwa pada perlakuan yang diberi pupuk dan tanpa pupuk (kontrol) menghasilkan jumlah anakan rumput setaria yang sedikit berbeda. Hasil ini sedikit lebih rendah dibandingkan dengan jumlah anakan pada defoliasi pertama yaitu sebesar 21 anakan untuk perlakuan P1 dan P2, sedangkan perlakuan kontrol menghasilkan jumlah anakan sebanyak 13 anakan (Mauri et al., 2021). Koretjang et al. (2019) juga memberikan hasil yang sedikit lebih tinggi yaitu 17 jumlah anakan rumput setaria dengan perlakuan pupuk organik bokashi kotoran ayam dengan dosis 20 ton/ha. Berdasarkan hasil ini dapat dinyatakan bahwa pupuk organik kotoran satwa kuskus yang diberikan masih dapat dimanfaatkan oleh akar rumput setaria untuk akumulasi hara pada defoliasi kedua untuk menunjang pertumbuhan sehingga menghasilkan jumlah anakan. Hal ini sesuai Muhakka et al. (2013) bahwa ketika ruang tumbuh tanaman dan unsur hara cukup tersedia di dalam tanah atau media tanam sesuai dengan kebutuhannya maka akan semakin banyak menghasilkan individu tanaman yang baru.

Uji lanjut BNJ menunjukkan bahwa perlakuan Po berbeda nyata dengan perlakuan $\mathrm{P}_{1}$ dan $\mathrm{P}_{2}$, namun perlakuan P1 tidak berbeda dengan P2. Hal ini karena pupuk kotoran satwa kuskus memberikan pengaruh langsung terhadap proses fisiologi tanaman sehingga membantu meningkatkan pertumbuhan jumlah anakan. Lakitan (2007) menyatakan bahwa pemberian pupuk kandang akan memperbaiki struktur tanah sehingga meningkatkan pertumbuhan akar tanaman dari pori-pori tanah sehingga memudahkan tunas-tunas baru tumbuh menembus permukaan tanah.

Selain itu menurut Sawen (2012), bahwa selama kebutuhan unsur hara, air maupun cahaya pada tanaman tidak terjadi persaingan, maka laju fotosintesis pada proses pertumbuhan relatif sama dan menyebabkan jumlah anakan juga akan relatif sama (Sawen dan Nuhuyanan, 2020). Selain itu akumulasi haranya telah banyak diserap pada periode pertumbuhan sebelumnya saat defoliasi pertama, sehingga yang tersisa yang dimanfaatkan oleh tanaman setaria.

Hasil penelitian ini lebih rendah bila dibandingkan dengan hasil penelitian yang dilaporkan oleh Niknik et al. (2014) bahwa ata-rata jumlah anakan rumput Setaria sphacelata dengan pemberian pupuk organik kotoran ayam petelur dengan dosis 98 gram/rumpun yang dipanen pada umur 90 hari yaitu 18,25 anakan. Hasil lainnya, diperoleh bahwa jumlah anakan rumput setaria yang diberi pupuk kotoran kambing $300 \mathrm{~g} /$ polybag adalah 20,42 anakan (Suningsih et al., 2019). Selanjutnya dinyatakan bahwa pupuk organik asal kotoran ternak juga memberikan pengaruh langsung terhadap proses fisiologis tanaman sehingga dapat meningkatkan pertumbuhan rumput setaria seperti mengokohkan akar, pertumbuhan lebar atau luas daun meningkat termasuk batang dan jumlah anakan.

\section{Jumlah Daun}

Daun merupakan organ tanaman tempat berlangsungnya proses fotosintesis yang memproduksi makanan untuk kebutuhan tanaman maupun sebagai cadangan makanan. Daun sangat berhubungan dengan proses fotosintesis, karena mengandung klorofil yang diperlukan oleh tanaman dalam proses fotosintesis, semakin banyak jumlah daun maka hasil fotosintesis semakin tinggi, sehingga tanaman tumbuh dengan 
baik (Ekawati, 2017).

Berdasarkan Tabel 1, ketiga perlakuan memberikan respon jumlah daun rumput setaria yang berbeda dan meningkat dengan adanya penambahan pupuk kotoran kuskus. Walaupun secara statistik (Anova), perlakuan tidak memberikan pengaruh yang signifikan terhadap jumlah daun. Namun jumlah daun yang dihasilkan pada perlakuan P1 (75 helai daun) dan P2 (65 helai daun) cenderung lebih banyak dibandingkan dengan perlakuan Po (tanpa pemupukan) sebanyak 60 helai daun rumput setaria. Hasil ini juga berbeda dengan jumlah daun yang dihasilkan pada defoliasi pertama yaitu perlakuan P2 sebanyal 102 helai daun, P1 sebanyak 101 helai daun dan perlakuan control sebanyak 71 helai daun setaria (Mauri et al., 2021).

Hal ini menunjukkan bahwa pada perlakuan P1 dan P2 adalah perlakuan yang cenderung dapat menyediakan unsur hara yang seimbang dan meningkatkan pertumbuhan jumlah daun rumput setaria. Pupuk organik mengandung asam humat dan asam folat serta zat pengatur tumbuh yang dapat mempercepat pertumbuhan tanaman (Supartha et al., 2012). Frekuensi pemberian pupuk dengan dosis yang berbeda menyebabkan hasil produksi jumlah daun yang berbeda pula dan frekuensi yang tepat akan mempercepat laju pembentukan daun. Hal ini juga berkaitan dengan peranan $\mathrm{N}$ sebagai komponen klorofil. Bertambahnya unsur N dalam tanah berasosiasi dengan pembentukan klorofil di daun sehingga meningkatkan proses fotosintesis yang memacu pertumbuhan jumlah daun tanaman.

Selain itu, unsur hara yang ada pada tanah merupakan sisa unsur hara yang masih mengandung pupuk kotoran kuskus sebagai perlakuan pada defolasi sebelumnya yang berakumulasi dan diserap oleh akar rumput setaria sehingga mampu menghasilkan pertambahan jumlah daun yang optimal dengan unsur hara yang ada. Hadisuwito (2012) juga menyatakan bahwa peran utama nitrogen bagi tanaman adalah untuk merangsang pertumbuhan tanaman secara keseluruhan khususnya batang, cabang dan daun. Selain itu fungsi unsur N yaitu penting dalam pembentukan protein dan zat hijau daun atau klorofil. Secara visual kecukupan $\mathrm{N}$ pada tanaman dapat ditandai pula dengan indikator warna hijau daun pada tanaman yang dihasilkan saat pertumbuhan vegetatif (Munawar, 2011). Hasil penelitian ini lebih tinggi jika dibandingkan dengan hasil penelitian yang dilaporkan oleh Sahlan et al. (2018) bahwa rata rata jumlah daun rumput Setaria splendida dengan dosis 40 gram per pot yaitu 92 daun (helai). Hal ini bisa juga karena kandungan unsur hara pupuk organik feses kuskus berupa nitrogen $(\mathrm{N})$, fosfor $(\mathrm{P})$ dan kalium (K). Hasil analisis kandungan feses kuskus antara lain pada Tabel 2, memperlihatkan bahwa unsur hara pada pupuk kotoran kuskus mampu memberikan pengaruh yang signifikan untuk menunjang dalam proses fotosintesis sehingga menghasilkan pertumbuhan tanaman yang baik dalam hal ini pertambahan jumlah daun setaria yaitu $\mathrm{N} 0,85 \%$ untuk feses berbasis pakan pisang, dan $\mathrm{N}$ 0,76\% untuk feses berbasis avokad (Mauri et $a l, 2021)$. Selain itu pada penelitian ini juga lebih tinggi bila dibandingkan dengan hasil penelitian yang dilaporkan oleh Nuriyasa et al. (2012) bahwa jumlah daun rumput setaria dengan perlakuan pupuk biourin sapi dengan dosis 500 liter/ha yaitu 32,33 helai. Darmawan (2013) menyatakan bahwa nitrogen yang tinggi pada pupuk organik dapat memacu proses pembentukan daun tanaman, karena $\mathrm{N}$ merupakan unsur penyusun asam amino dan protein, sebagai bahan dasar dalam penyusunan daun. Selanjutnya peningkatan jumlah daun dan luas daun akan meningkatkan laju pertumbuhan tanaman karena asimilat yang terbentuk sebagai produk fotosintesis akan dimanfaatkan untuk membentuk sel-sel yang baru pada organ vegetatif (Situmeang, 2020).

\section{SIMPULAN DAN SARAN}

Pemberian perlakuan pupuk organik kotoran satwa kuskus berbasis pakan pisang dan avokad dengan dosis 40 gram per polybag dapat meningkatkan pertumbuhan rumput Setaria sphacelata dengan pertambahan tinggi tanaman sebesar 45-54 cm, jumlah anakan sebesar 11-16 anakan dan jumlah daun sebanyak 60-75 helai daun pada defoliasi kedua. Pupuk kotoran satwa kuskus dapat digunakan sebagai pupuk organik. Dengan demikian kotoran atau feses satwa pada penangkaran dapat dimanfaatkan sebagai pupuk organik. Selanjutnya perlu diujicobakan perlakuan dengan dosis pupuk yang berbeda untuk membandingkan respon produkstivitasnya.

\section{DAFTAR PUSTAKA}

Darmawan, A.F., N. Herlina, dan R. Soelistyono, 2013. Pengaruh berbagai macam bahan organik dan pemberian air terhadap pertumbuhan dan hasil tanaman sawi (Brassica juncea L.). Jurnal Produksi Tanaman, 1 (5), 389-397.

Ekawati, R. 2017. Pertumbuhan dan Produksi Pucuk kolesom pada intensitas cahaya rendah. Jurnal Kultivasi, 16 (3), 412-417. https://doi. org/10.24198/kultivasi.v16i3.13719.

Fadludin, S. H. 2013. Penggunaan level pupuk organik granul terhadap luas dan jumlah daun rumput gajah pada defoliasi ke dua. Jurnal Agriplus 1 (1), 109-118.

Hadisuwito, S. 2012. Membuat Pupuk Kompos Cair. Jakarta: Agromedia Pustaka. 
Hardjowigeno, S. 2007. Ilmu Tanah. PT. Raja Grafindo Persada: Jakarta.

Hartono, B. 2011. Produksi dam kandungan nutrisi rumput setaria (Setaria sphacelata) pada pemotongan pertama yang diberi pupuk kandang feses kambing dengan dosis berbeda. Jurnal Produksi Tanaman, 20-23.

Korejang, M, S. D. Anis, W. B. Kaunang, dan C. I. I. J. Sumolang. 2019. Respon pertumbuhan rumput Brachiaria humidicola cv Tully dengan pemberian pupuk organic bokashi kotoran ayam petelur. Zootec, 39 (1), 33-41. https://doi. org/10.35792/zot.39.1.2019.22120.

Lakitan, B. 2007. Dasar-dasar Fisiologi Tumbuhan. Jakarta : PT Raja Grafindo Persada.

Lingga, P. 2002. Petunjuk Penggunaan Pupuk. Jakarta: PT. Penebar Swadaya.

Marliani. 2010. Produksi dan kandungan gizi rumput setaria (Setaria sphacelata) pada pemotongan pertama yang ditanam dengan jenis pupuk kandang yang berbeda. Riau: Universitas Islam Negeri Sultan Syarif Kasim.

Mauri, F.R.S., D. Sawen dan A. Baaka. 2021. Respon Pertumbuhan Rumput Setaria (Setaria sphacelata) yang diberikan pupuk Kotoran Satwa kuskus asal Penangkaran. Jurnal Sains dan Teknologi Peternakan, 2 (2), 74-81.

Muhakka, A. 2012. Pengaruh pemberian pupuk cair terhadap produksi rumput gajah Taiwan (Pennisetum purpureum schumach). Jurnal Peternakan Sriwijaya, 1 (1), 48-54.

Munawar, A. 2011. Kesuburan Tanah dan Nutrisi Tanaman. Bogor: IPB Press.

Niknik, A. Marsuki dan S. Bambang. 2014. Pemberian pupuk organik ayam petelur dan konsentrasi EM4 dalam meningkatkan Produksi rumput Setaria (Setaria sphacelata). Jurnal Ilmiah Inovasi, 14(1), 20-23.

Nuriyasa, I M., Candraasih K., N. N., A. A. A S. Trisnadewi, E. Puspani, dan W. Wirawan. 2012. Peningkatan produksi rumput gajah (Pennisetum purpureum) dan rumput setaria (Setaria sphacelata) melalui pemupukan biourin. Jurnal Pastura, 1 (2): 93-96. Sumber: https:// ojs.unud.ac.id/index.php/pastura/article/ view/9029/6827.
Sahlan, M., I W. Suarna dan N. G. K. Roni. 2018. Pengaruh berbagai jenis pupuk organic terhadap produktivitas rumput Panicum maximum, Setaria sphacelata dan Pennisetum purpureum. Jurnal Pastura, 8(1), 13-19.

Salisbury, F. B., and C. W. Ross. 1995. Fisiologi Tumbuhan. ( $3^{\text {rd }}$ ed., Vol. 343). Bandung: ITB Bandung.

Sawen, D. 2012. Pertumbuhan Rumput Gajah (Pennisetum perpureum) dan Benggala (Panicum maximum) Akibat Perbedaan Intensitas Cahaya. JITT. 2: 17-20.

Sawen, D. dan L. Nuhuyunan. 2020. Respon pertumbuhan rumput gajah (Pennisetum purpureum), Setaria (Setaria sphacelata) dan Benggala (Panicum maximum) terhadap perbedaan salinitas. Jurnal Pastura, 10 (1):1317. Sumber: https://ojs.unud.ac.id/index.php/ pastura/article/view/66708/37203

Sawen, D. dan A. Sineri. 2020. The feed plants species of cuscus Phalanger orientalis in Yamna Island Sarmi Regency. WJARR: word journal of Advanced Research and Reviews, 06(01), 031039.

Situmeang, Y. P. 2020. Biochar Bambu perbaiki kualitas tanah dan hasil jagung. in. Y.P. Situmeang (Ed). Surabaya: Scopindo Media Pustaka.

Steel, R. G. D. dan J. H. Torrie1993. Prinsip dan Prosedur Statistika (Pendekatan Biometrik). Jakarta: Gramedia Pustaka Utama.

Suningsih, N., Noproda, H., dan Feryanto. 2019. Pertumbuhan dan produksi rumput setaria (Setaria splendida Stapf) sebagai Pakan ternak ruminansia pada tanah ulisol dengan penambahan pupuk kotoran kambing. Seminar nasional Lahan Suboptimal, Palembang 4-5 September (pp. 201-210). Palembang: Unsri Press

Supartha, I N. Y., G. Wijana dan G. M. Adnyana. 2012. Aplikasi jenis pupuk organik pada tanaman padi sistem pertanian organik. Jurnal Agroteknologi Tropik, 1 (2): 98-106.

Wulandari N. K. A, I N. Kaca, dan N. K. E. Suwitari. 2021. Pengaruh pemberian kotoran ternak sapi dan kambing dengan dosis berbeda terhadap kualitas Rumput setaria (Setaria sphacelata). Jurnal Gema Agro, 01, 72-77. 